\title{
ESTUDO CINÉTICO DA REAÇÃO DO POLI (L-ÁCIDO LÁCTICO) VIA POLICONDENSAÇÃO DIRETA COMO BIOPOLÍMERO DE APLICAÇÃO MÉDICA
}

Samuel Diógenes Azevedo de Souza*, Profa. Dra. Maria Regina Wolf Maciel, Prof. Dr. Rubens Maciel Filho, Dr. André Luiz Jardini Munhoz, Prof. Dr. Viktor Oswaldo Cárdenas Concha, Dra. Maria Ingrid Rocha Barbosa Schiavon.

\section{Resumo}

O presente trabalho aborda o estudo cinético da reação de policondensação direta na obtenção do Poli (l-ácido láctico) (PLLA) em função da concentração do PLLA formado em relação ao tempo de reação (18h). Variáveis como temperatura, porcentagem de catalisador e co-catalisador, foram estudadas anteriormente, no intuito de obter a melhor região do processo de obtenção do PLLA. Foram coletadas amostras a cada 4 h de reação, analisadas pela técnica de cromatografia por permeação em gel (GPC), e os resultados foram observados levando em conta a massa molar média de formação de PLLA para cada instante de tempo. Portanto, foi possível levantar a curva de cinética de formação do polímero da concentração por tempo.

\section{Palavras-chave:}

poli (l-ácido láctico), policondensação direta, cromatografia por permeação em gel.

\section{Introdução}

No país, algumas doenças que levam a internação hospitalar, e principalmente, as lesões traumáticas, oneram as contas públicas do sistema de saúde brasileiro. Por tal motivo, a busca pela síntese de biomateriais que promovam, precisamente, a cicatrização e a regeneração do organismo, favorecendo a melhora na qualidade de vida dessas pessoas, vem crescendo conforme 0 avanço nas pesquisas ${ }^{5}$. Dentre a gama de biomateriais existentes, o PLLA possui grande aceitação na Engenharia Tecidual, por sua excelente biocompatibilidade e seu comportamento biorreabsorvível, servindo para diversas aplicações como implantes temporários ${ }^{2,5}$.

Para sua síntese, as rotas convencionais são por abertura do anel láctico, e pela policondensação direta do ácido I-láctico. Neste trabalho, optou-se pela rota da policondensação pela facilidade para construção do sistema em laboratório, e também sabendo que 0 produto representa um polímero de baixa massa molar ${ }^{4}$.

Com base na literatura e em trabalhos abordados pela equipe do INCT-Biofabris, a primeira etapa envolve a desidratação do ácido I-láctico (a temperatura de $130^{\circ} \mathrm{C}$ por um período de 2,5 horas), e a segunda etapa, consiste na adição do catalisador (Octanoato de estanho II), a $160^{\circ} \mathrm{C}$ em proporção de $1 \%$ de massa em relação a quantidade de ácido I-láctico, e em continuidade, a adição do co-catalisador (1dodecanol) a $0,025 \%$ da razão mássica do ácido |láctico ${ }^{4}$. Essas proporções seguiram condições específicas, aceitas para aplicação no organismo ${ }^{1}$.

Foram coletadas amostras a cada 4 horas para o levantamento do estudo cinético por GPC, sendo que, a reação terminou em 18 horas. $A$ análise de determinação da massa molar relativa (convencional), foi realizada com um equipamento da Viscotek composto por um amostrador GPCmáx modelo VE 2001, e um arranjo de três detectores modelo TDA 302, no qual, para analise somente o detector de índice de refração foi usado.

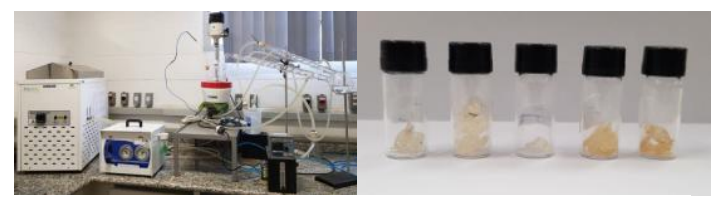

Figura 1. Reator e amostras coletadas para GPC.

Resultados e Discussão

Mediante 0 exposto, o GPC obteve-se as massas molares de um pré-polímero ${ }^{3}$ que resultaram no levantamento cinético e na análise da velocidade de reação, no qual a reação em primeira ordem apresentou as melhores condições.

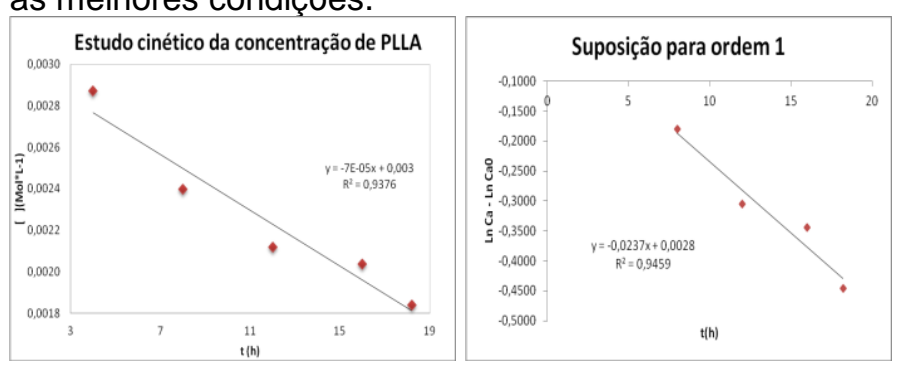

Figura 2. Estudos utilizando métodos cinéticos.

\section{Conclusões}

O tempo de polimerização estudado não foi suficiente para garantir a formação de um polímero, contudo, é possível esperar que, em um tempo de reação maior, forme-se o polímero de baixa massa molar.

${ }^{1}$ CUNHA, B. L. de C. Produção e otimização do PLA (poliácido láctico) via policondensação direta visando sua aplicação na área biomédica. 2018. Universidade Federal de São Paulo, [s. 1.], 2018.

${ }^{2}$ JAHNO, V. D. Síntese e caracterização do poli (L-ácido láctico) para uso como biomaterial. 2005. Universidade Federal do Rio Grande do Sul, [s. 1.], 2005.

${ }^{3}$ LASPRILLA, A. J. R. Síntese do poli-ácido láctico a partir do ácido láctico para aplicação biomédica. 2011. 138 p. Dissertação (mestrado) Universidade Estadual de Campinas, Faculdade de Engenharia Química, Campinas, SP.

${ }^{4}$ PATTARO, A. F. Síntese, Caracterização e Processamento de Polímeros Biorreabsorvíveis para uso na Engenharia de Tecidos (Tissue Engineering). 2016. Universidade Estadual de Campinas, [s. 1.], 2016.

${ }^{5}$ SILVA, K. N.; FILHO, R. M.; MUNHOZ, A. L. J.; CONCHA, V. O. C.; SCHIAVON, M. I. R. B.; SOUZA, R. A. Síntese de poli (L-ácido lático) (PLLA) visando sua utilização como implantes biomédicos. Revista dos Trabalhos de Iniciação Científica da UNICAMP, n. 26, 23 jan. 2019. 